\title{
Enforcement of Personal Service Contracts in the Entertainment Industry
}

\section{David Tannenbaum*}

TF THE entertainment industry can rightfully claim the parentage of any single set of legal principles, those principles are the ones that a court of equity uses today in aiding employer's demand for specific performance of contracts for personal service by public performers.

Many of these principles, it is true, are found interlaced among the broad, general rules and inaxims that govern all suits in equity. Among the working rules which govern the discretion of equity in each of these cases are found an insistence upon the readiness and ability of the employer to perform, the requirement that the contract be not oppressive nor unconscionable, that it was not entered into by mistake and that the employer himself coines into equity with clean hands. But the single, well-accepted primciple that, under appropritate circumstances, equity will enjoin the breach of a covenant in an artiste's contract not to perform for others, can be traced back directly to the landinark case of Lumley $v$. Wagner, ${ }^{1}$ decided 101 years ago.

The seed sown by Lumley v. Wagner has blossomed forth fully in the modern day entertainment contract. This is especially so in the motion picture field where the contracts between performers and their studios contain many elaborate provisions designed to insure the einployer that the employee will perforin for him, and for no one else. ${ }^{2}$ Briefly summarized,

* Member, Los Angeles Bar.

${ }^{1}$ I De G.M. \& G. 604, 42 Eng. Rep. 687 (1852).

2 The following is a typical recital of provisions found in many motion picture contracts today:

During the term hereof the artist will not render his services as an actor, nor will he pose, act, appear, write, direct or render any other services in any way connected with motion pictures or photoplays, nor will he render any services of any kind or character whatsoever in any way connected with dramatic, theatrical, musical, vaudeville, radio, television or other productions, shows, perfornances and/or entertainment, nor will he render any other similar services to or for himself or to or for any other person, firm or corporation other than the producer without the prior written consent of the producer. The artist further agrees that he will not consent to nor permit any other person to advertise, annonnce or make known, directly or indirectly, by paid advertisements, press notices, or otherwise, that he has contracted to do or perform any act or services contrary to the terms of this agreement. The producer shall have the right to institute any legal proceedings in the name of the artist or otherwise to prevent such acts or any of them.

It is distinctly understood and agreed that the services to be rendered by the artist herennder and the rights and privileges herein granted to the producer by the artist are of a special, umque, unusual, extraordinary and intellectual character which gives them a peculiar value, the loss of which cannot be reasonably or adequately compensated in damages in an action at law and that a breach by the artist of any of the provisions contained herein will cause the producer irreparable injury and damage. The artist expressly agrees that the producer shall be entitled to injunctive or other equitable relief to prevent a breach of this agreement by the artist. 
the major provisions of such clauses include a covenant under which the employee agrees to devote his services exclusively to the employer, a covenant forbidding the employee from performing in any fashion for any other employer, a stipulation that the services of the employee are of a "special, unique, unusual, extraordinary and intellectual character," and a stipulation that the employer may seek injunctive relief to prevent breach of any of the contract's terms.

Despite the stringency of such contract clauses, it is not in every case that equity will afford relief to a theatrical employer whose performer declines to fulfill his contractual obligation. For a better understanding of the cases in which equity will and will not act, it is necessary to re-examine the Lumley v. Wagner doctrime and to trace its development through the subsequent century.

\section{Lumley v. Wagner}

In Lumley v. Wagner, Lord St. Leonards was confronted with an agreement under which the defendant opera singer had agreed to sing at plaintiff's theater from the first of April to the first of July following the date of the contract. The agreement contained an express negative covenant whereby defendant contracted not to sing elsewhere during that period. Defendant was about to sing for a competitor of plaintiff's during the prohibited time.

Though admitting his inability to specifically enforce the entire contract, the chancellor granted an injunction restraining defendant from performing at the rival theater. The chancellor ignored the fact that the remedy obtained was not mutually available, but said that while he was not trying to do indirectly that which he could not do directly, nevertheless if the injunction tended to cause the defendant to perform her contract with plaintiff, so much the better. Alas, for the chancellor's wishful thinking, since history tells us Madame Wagner did not so perform.

Another English court ${ }^{3}$ extended the Lumley doctrine so far as to imply a negative covenant in an employment agreement which the court then proceeded to enforce, but this extension was criticized and repudiated in the later case of Whitwood Chemical Co. v. Hardman. ${ }^{4}$ In the latter case, Lord Justice Lindley expressed displeasure with the Lumley rule, declaring " ... the court, looking at the matter broadly, will generally do much more harm by attempting to decree specific performance in case of personal service than by leaving them alone; and whether it is attempted to enforce these contracts directly by a decree of specific performance, or indirectly by an injunction, appears to me to be immaterial."

3 Montague v. Flockton, 42 L.J.R.N.S. 677 (1873).

4 [1891] 2 Ch. 416. 
Generally speaking, the American courts have followed Lumley v. Wagner, though they occasionally confess to the same misgivings that troubled Lord Justice Limdley. The rationale of the American cases has been expressed by Professor Williston im his work on contracts, ${ }^{5}$ and also in the Restatement of Contracts, ${ }^{6}$ as being that the injunction should only be granted wliere the performance of defendant's negative obligation has some value in itself to plaimtiff over and above the possibility that defendant may thus be induced to perform his affirmative obligation. ${ }^{7}$

Translated into everyday terms, Professor Williston's theory means the existence or nonexistence of competition between the plaintiff and the third party for whom the defendant seeks to perform or the medium in which the defendant seeks to perform. If defendant proposes to sing at a theater across the street from plaintiff's, as in Lumley v. Wagner, clearly there would be additional value to plaintiff in enforcing the negative covenant and thus preventing the loss to a competitor of plaintiff's prospective patrons, even though plaintiff could not liave defendant's services. On the other hand, under Professor Williston's view, where defendant would appear in some remote part of the world in such a fashion that there could be no conceivable competitive situation existing between plaintiff and defendant's new employer, it would appear that there would then be no independent value to plaintiff from the enforcement of defendant's negative undertaking.

The English courts do not share Professor Williston's view. In one case an English court enjoined an actor from accepting employment in London after the actor had returned to England from the United States where his employer, the plaintiff, was still on tour with a travelling stock company

5 See 5 WnIISTON, Contracis $\$ 1450$ (Rev. ed. 1937) at 4051 where the author says: In most of the decisions, however, the negative undertaking of the defendant had importance to the plaintiff apart from the pressure which its enforcement would put upon the defendant to perform his affirmative undertaking, and if the defendant's performance of his negative obligation has no value to the plaintiff in itself an injunction will not generally be granted. In other words, the courts have shown a disinclination to enforce negative covenants in such a contract where the effect would be to compel the employee either to remain idle, deprived of his earning power, or to perform the positive covenants. In general, it is not the mere taking of new employment but unfair competition which equity enjoins.

6 Restatement, Contracts $\$ 380$ (1) (a) (1932).

7 See De Pol v. Sohlke, 30 N.Y. Super. 280 (1867) at 281 , where the court said:

If, then, the object of the restrictive clause was to prevent the defendant Sohlke from dancing for others, without any substantial benefit to arise therefrom to the plaintiffs, an injunction should not issue. Now what benefit can arise to the plaintiffs from such prevention? It is said that if she is prevented from gaining her livelihood in the employment of others, she will necessarily be obliged to keep her contract with the plaintiffs. Even conceding for the purposes of this motion, that the conclusion drawn from the premises of this argument is correct, still such expected benefit is insufficient to authorize an injunction. It is calling on the court to effect indirectly that which it refuses to do directly, viz: to compel a specific performance. That, I for one, decline to do. 
which defendant had left. ${ }^{8}$ Obviously, no competitive injury could have resulted to plaintiff under these facts. Recently, in the case of Marco Productions Ltd. v. Pagola, ${ }^{9}$ an Englisl court rejected the Williston argument and held squarely that a failure on plaintiff's part to prove that le suffered any damages arising from the breach of the negative covenant would not alone bar the issuance of an injunction.

The problem of competition becomes more difficult in the case of different media in whicl defendant may perform. The stipulation mentioned above that is customarily found in motion picture contracts should be treated by the court as some evidence that the parties themselves regard this media as being competitive. Assume the existence of such a contract calling for the rendition of services im a film and providing that the employee should not appear during the prescribed term in any other film or theater, or on radio or television. Under such circumstances, would a court enjoin the performer from making a radio appearance? The English cases cited above suggest that a master in chancery miglit be sympathetic to the issuance of an injunction even though he might hold that radio was not directly competitive to a motion picture film. The American courts, however, would probably follow Williston's theory and refuse to issue the injunction unless the court found as a fact that the media was directly competitive. In any event, no American case has been found in this field where a competitive situation was not involved.

\section{The "Unique and Extraordinary Services" Rule}

American courts have consistently followed the rule that the services of the defendant who is souglit to be enjoined must be "of a special, unique, unusual, extraordinary or intellectual character" before an injunction may issue to restrain the offering of these services to another. Within the framework of this rule, injunctive relief has been souglit against breach of negative covenants by not only actors ${ }^{10}$ and actresses, ${ }^{11}$ but also acrobats, ${ }^{12}$

8 Grimston v. Cuningham, [1894] 1 Q.B. 125.

9 [1945] 1 K.B. 111.

10 Carter v. Ferguson, 12 N.Y. Supp. 580 (1st Dep't 1890); Hallam v. Harvey, [1901] 1 S.R.N.S.W. 155; Montague v. Flockton, 42 L.J.R.N.S. 677 (1873); Palace Theatre Ltd. v. Clensey, 26 T.L.R. 28 (1909); Webster v. Dillon, 3 Jur. N.S. 432, 5 W.R. 867 (1857); Grimston v. Cuningham, [1894] 1 Q.B. 125; Harry Hastings Attractions v. Howard, 196 N.Y. Supp. 228 (Sup. Ct. 1922) ; Harry Rogers Theatrical Enterprises Inc. v. Comstock, 232 N.Y. Supp. 1 (1st Dep't 1928).

11 Canary v. Russell, 30 N.Y. Supp. 122 (Sup Ct. 1894); Daly v. Smith, 49 How. Pr. 150 (1874); Duff v. Russell, 14 N.Y. Supp. 134 (Super. Ct. 1891); Keith v. Kellermann, 169 Fed. 196 (C.C.S.D.N.Y.1909); McCaull v. Braham, 16 Fed. 37 (C.C.S.D.N.Y. 1883) ; Shubert v. Angeles, 80 N.Y. Supp. 146 (1st Dep't 1903); Warner Bros. Pictures Inc. v. Nelson, [1937] 1 K.B. 209.

12 Marco Productions Ltd. v. Pagola, [1945] 1 K.B. 111; Shubert Theatrical Co. v. Rath, 271 Fed. 827 ( (2d Cir. 1921). 
dancers, ${ }^{13}$ minstrel singers, ${ }^{14}$ musicians, ${ }^{15}$ radio commentators, ${ }^{16}$ a theatrical booking agent, ${ }^{17}$ baseball players, ${ }^{18}$ boxers ${ }^{10}$ and a jockey. ${ }^{20} \mathrm{~A}$ Texas court has even gone so far as to enjoin a public school music teacher from contracting for employment in another public school. ${ }^{21}$

Evidently, the English courts are not impressed by this "umique and extraordinary services" rule. Thus, one English court ${ }^{22}$ enjoined a five pound per week stock company understudy whose services presumably were neither special nor unique. Another English court ${ }^{23}$ enjoined an 18 shilling a week ballet dancer and, in the course of its opinion, denied the argument presented by defendant's counsel that an injunction could only lie if the performer had already achieved some degree of eminence. The court expressly said that it would not trouble itself to determine whether or not a particular performer had achieved greatness before it would enjoin her. It is interesting to note that none of these so-called magic adjectives are to be found in the Lumley v. Wagner opmion, though the facts of that case would clearly give support to the rule.

It has been suggested ${ }^{24}$ that this rule entered our jurisprudence through the influence of Professor Pomeroy who used these words in attempting to define the rule of the cases for his earlier work on equity. Whatever be the reason, we now recognize that the "unique and extraordinary" rule is firmly implanted in our use of the basic doctrine. Such language appears in each of the California Code Sections that deals with such injunctive relief. ${ }^{25}$

Assuming that this yardstick must be met, how does one go about proving the uniqueness or nonuniqueness of defendant's services? The recital in the employment contract that the services to be rendered are unique and extraordinary has been admitted into evidence in one case as an admission

13 Comstock v. Lopokowa, 190 Fed. 599 (C.C.S.D.N.Y. 1911); Hoyt v. Fuller, 19 N.Y. Supp. 962 (Super. Ct. 1892) ; Lanner v. Palace Theatre Ltd., 9 T.L.R. 165 (1893); Nazarro v. Washington, 81 N.Y.S.2d 769 (Sup. Ct. 1948).

14 Dockstrader v. Reed, 106 N.Y. Supp. 795 (1st Dep't 1907).

15 See Dossor v. Monaghan, [1932] North Ire. L.R. 209; Okeh Phonograph Corp. v. Armstrong, 63 F.2d 636 (9th Cir. 1933).

${ }_{16} \mathrm{~J}$. Walter Thompson Co. v. Winchell, 278 N.Y. Supp. 781 (1st Dep't 1935).

17 See Frederick Bros. Artists Corp. v. Yates, 61 N.Y.S.2d 478 (Sup. Ct. 1946), revcrsed, 62 N.Y.S.2d 714 (1st Dep't 1946).

18 Amer. Ass'n Baseball Club v. Pickett, 8 Pa. Co. Ct. Rep. 232 (1890); Cincinnati Exhibition Co. v. Marsans, 216 Fed. 269 (D. Mo. 1914); Philadelphia Ball Club v. Lajoie, 202 Pa. 210, 51 Atl. 973 (1902).

19 Madison Square Garden Corp. v. Carnera, 52 F.2d 47 (2d Cir. 1931).

${ }^{20}$ See Cain v. Garner, 169 Ky. 633, 185 S.W. 122 (1916).

21 Mission Independent School Dist. v. Diserens, 144 Tex. 107, 188 S.W.2d 568 (1945).

22 Grimston v. Cuningham, [1894] 1 Q.B. 125

23 Lanner v. The Palace Theatre Ltd., et al, 9 T.L.R. 165 (1893).

24 See Garrett, Negative Specific Performance of Personal Service Contracts, 2 BayLoR L. REv. 189 (1950).

25 Cat. Ctv. Code § 3423(5); Cal. Code Civ. Proc. § 526(5); Cal. Labor Code § 2855. 
on the part of the performer to be weighed against his conflicting affidavit to the contrary. ${ }^{26}$ On the other hand, many courts have held that the stipulation of the parties will not stand against the court's own finding to the contrary. ${ }^{27}$ As evidence tending to prove uniqueness, some American producers have offered the testimony of veteran fellow producers that they have "never seen anything hike the defendant's act in all their years of experience." 28 Others have offered newspaper comments regarding the uniqueness of the performers. ${ }^{29}$ Opposed to the testimony of these witnesses has been that offered by defendants seeking to prove that they were just runof-the-mill performers whose talents should not be elevated to an enjoinable level. Such testimony has included low billing on the program ${ }^{30}$ and a showing of moderate salary. ${ }^{31}$ As noted above, salary arguments have not proven too effective with British courts. But in California, for example, our Code Sections require a minimum compensation at the rate of $\$ 6,000$ per annum before any such injunction may even be considered. ${ }^{32}$

Clearly related to the "unique and extraordinary" stipulation found in most well-drawn contracts is a stipulation, found in many contracts, concerning liquidated damages in the event of breach by the defendant. Such a clause does not, by itself, make nonenforceable a contract which might otherwise be specifically enforced or upon which an injunction against breach of the negative covenant might issue. Nevertheless, there is always the danger that the existence of a liquidated damages clause in a contract may cause the court to feel that the employee's services are not unique if the liquidated damage figure is a small or nommal one, or that the parties fairly well estimated by their agreement the damages that the plaintiff might suffer, thus indicating that damages are fairly susceptible of ascertainnient. In two cases ${ }^{33}$ containing such provisions, the courts declined to issue injunctions against the breach of the negative covenant, though in another case, ${ }^{34}$ a clause providing that for each breach of the negative covenant the performer would forfeit one week's salary was held to be a mere penalty to induce performance, and, therefore, not to bar injunctive relief.

${ }^{26}$ Harry Rogers Theatrical Enterprises Inc. v. Comstock, 232 N. Y. Supp. 1 (1st Dep’t 1928).

27 For example, Dockstrader v. Reed, 106 N.Y. Supp. 795 (1st Dep't 1907), and Frederick Bros. Artists Corp. v. Yates, 61 N.Y.S.2d 478 (Sup. Ct. 1946), reversed, 62 N.Y.S.2d 714 (Ist Dep't 1946).

28 Shubert Theatrical Co. v. Rath, 271 Fed. 827 (2d Cir. 1921).

29 Harry Hastings Attractions v. Howard, 196 N.Y. Supp. 228 (Sup. Ct. 1922).

30 Carter v. Ferguson, 12 N.Y. Supp. 580 (1st Dep't 1890).

31 Butler v. Gallentti, 21 How. Pr. Rep. 465 (N.Y.Super.1861); Dockstrader v. Reed, 106 N.Y. Supp. 795 (1st Dep't 1907).

32 CAL. Civ. Code $\S 3423(5)$; CaL. Code Crv. Proc. $\$ 526(5)$.

33 Madison Square Garden v. Braddock, 90 F.2d 924 (3rd Cir. 1937) ; Mapleson v. Del Puente, 13 Abbott's N.C. 144 (N.Y. Super. 1883).

${ }^{34}$ McCaull v. Braham, 16 Fed. 37 (C.C.S.D.N.Y. 1883). 


\section{Option Contracts and Suspension Clauses}

Many motion picture contracts contain options whereby the employer may renew his right to the performance by the employee for additional periods of time beyond the current term of the contract. May a court enjoin the defendant employee for a period beyond the current term? The court has no way of knowing whether an employer will exercise his option unless the employer, pursuant to the contract, chooses to do so at the time he seeks the injunction. To enjoin the defendant employee for a period beyond the current term would obviously be unfair since the employer by not exercising his option might not be required to carry out his performance. A court of equity is not expected to continually police its judgments, so its decree, insofar as possible, should be complete at the time rendered. However, it would seem that a court could (a) enjoin the defendant for the current term and (b) the employer could, when he exercised the option, petition the court at that time for a continuation of the injunction. Though a court of equity in its sound discretion could issue an injunction beyond the current terin with the provision that the injunction should be dissolved if the option is not exercised, it is felt that the issuance of such an injunction is highly improbable.

An interesting question is posed in connection with the use of suspension clauses which are found in most motion picture employment contracts. Such clauses generally provide that the term of the contract itself may be extended for a period equal to the suspension, which suspension may be invoked by the employer where the employee has refused to perform. Under such circumstances, except for the seven year limitation on enforcement found in Labor Code Section 2855, the contract might be extended for the life of the employee. In such a case certainly no court would be expected to issue an injunction to enforce a negative covenant that might have the effect of keeping the employee from working in the media described in the contract for the remainder of his life.

In considering the case where an employee has first been suspended and the employer then seeks to enforce the negative covenant, the case of Loere's Inc. v. Cole ${ }^{35}$ should be noted. As a gratuitous dictum, the court went out of its way to declare that a negative covenant could not be enforced under such circumstances, declaring that it was void as an unlawful restraint on trade. Speaking of the particular contract, the court said: ${ }^{36}$

The provisions of the contract quoted above which purport to forbid Cole from practicing his profession during the period of suspension are manifestly void under the California Code. (Citing California Business and Professions Code Section 16600 in the footnote.) 
Suppose that a star of special and extraordinary ability refuses to work for no apparent reason. If the studio suspends the star under the terms of the contract, may the star then rightfully immediately violate the negative covenant by contracting with someone else, and, because of the suspension has the studio lost its right to obtain an injunction? It does not seem possible that such a result must follow from the dictum in the Cole case. Rather, it would seem, that the court in the exercise of its sound discretion should grant the injunction for the period requested and do so without requiring the employer to lift the suspension at that time provided that the employer declares himself ready to lift the suspension when and if the employee reports back to work. It should be remembered that if the suspension is lifted the employer once more becomes bound to pay a salary to the employee and it would indeed be a hardship on the employer if he obligated himself to begin salary payments immediately upon the granting of an injunction if the employee did not immediately return to work.

The British lawyers for Warner Brothers had a taste of this problem in the celebrated Bette Davis case. ${ }^{37}$ When Miss Davis refused to work for Warner Brothers she was suspended under her contract which provided that the term of the contract would be extended so long as the suspension continued. During the hearing on the apphication for the injunction in Britain while she was still under suspension, the judge indicated from the bench that he would hesitate to issue an injunction which conceivably might continue for the period of the suspension. Taking this hint, counsel for Warner Brothers on the third day of the hearing in open court, expressly waived the studio's right to suspend Miss Davis for her breach. With that obstacle out of the day, the court went on to issue the injunction as prayed. Apparently the English court was anxious to make a finding that the employer was ready, willing and able to perform its part of the contract, and the employer lifted its suspension with the expectation that the court would then find in its favor. It is submitted, for example, that within the sound discretion of a court of equity, an injunction might issue where an employee under a six month contract refuses to perform, is suspended, and immediate contracts to perform for a rival producer immediately after the expiration of the six month term. If no injunction were to issue here, the suspension clause would be valueless indeed.

\section{Negative Covenants as Post Performance Restraints on Competition}

One form of negative covenant which is found in certain entertainment industry contracts is the type which prohibits a performer from performing for another employer withm a designated period of time after he has com-

37 Warner Bros. Pictures Inc. v. Nelson, [1937] 1 K.B. 209. 
pleted his performance for the first employer. This form of agreement appears frequently in recording company contracts. In one Ninth Circuit case, ${ }^{38}$ Louis Armstrong had contracted not to record for any other company for three inonths following the completion of his contract for plaintiff, his employer. Nevertheless, Armstrong immediately contracted with a competitor to make records on the day following the end of his contract with plaintiff. The Circuit Court affirmed the trial court's denial of a preliminary injunction because of ambiguities in the contract that made its term uncertain, but said nothing about the fact that the negative covenant itself might be void as an unlawful restraint upon Armstrong's right to engage in his profession under California Business and Professions Code Section 16600 . Yet this same court was the one which brought in the Business and Professions Code Section referred to in the Cole case to declare that the negative covenant there involved was "manifestly void."

It would appear that if the term was for a reasonable time only, the court under the proper circumstances might issue an injunction although nothing in the Armstrong case lends support to such a belief.

It is interesting to speculate what the California courts might do if they were confronted with a covenant such as appeared in the recent English case of Higgs v. Olivier. ${ }^{39}$ The noted English actor had produced, directed and acted in the film, "Henry V," for which he had received his compensation in full. Two years later when the film was not going well in release, the producers decided that the box office might improve if Olivier abstained from making films for a while. In consideration of 15,000 pounds paid to him, Olivier entered a simple negative covenant not to produce, direct, or act in any film other than one for the producers for an eighteen month period. There was no obligation on the part of producers to furnish Olivier with a film, nor was there any affirmative covenant for Olivier to act in any film for them. Such a covenant as that entered into by Olivier would appear to be wholly void if it was sought to be enforced in this state, even thouglı it involyed a partial restraint limited in time and was not limited in profession since it did not bar Olivier from acting in the legitimate theater. Nevertheless, a legislative amendnient would be required to correct this situation in California, and it is suggested that this is a case where such a law might well be made. The injustice of allowing a person to default under such an agreenient would be great indeed.

\section{California Code Provisions}

Sections dealing with the right to injunctive relief in personal service contracts are found in our California Civil ${ }^{40}$ and Labor Codes ${ }^{41}$ as well as

38 Okeh Phonograph Corp. v. Armstrong, 63 F.2d 636 (9th Cir. 1933).

39 [1951] 1 Ch. 899.

40 CAI. CIV. Code $\$ 3423(5)$.

41 CAL. LABOR CODE $\$ 2855$. 
the Code of Civil Procedure. ${ }^{42}$ The sections in both the Civil Code and Code of Civil Procedure were amended to allow what appears to be specific performance of certain forms of personal service contracts after a District Court of Appeal case in $1918^{43}$ held that an injunction could not be granted to prevent the breach of a negative covenant where the performance of a compamion affirmative covenant could not be specifically enforced.

In the absence of any California case law interpreting these sections, ${ }^{44}$ we can only speculate as to whether the unusual wording of both sections was intended to place California in line with the Williston theory for allowing enforcement of negative covenants under competitive circumstances. Read literally, the sections apparently permit enforcement of the affirmative obligation to perform or, at least by inference enforcement of the negative covenant where the only benefit to plaimtiff thereby would be the inducement for the defendant to perform his affirmative covenant.

\section{Conclusion}

An endeavor has been made in this article to consider the working rules which should guide the courts of equity in the exercise of their sound judicial discretion in determining whether an injunction should be issued which would bar an employee from violating his negative covenant. However, all of the rules cannot be expressed lierem.

The facts and circumstances of each case may be expected to be peculiar unto themselves and determined accordingly by a court seeking to do justice without deprivation of the liberty of the employee, which liberty is so basic and important to all.

42 Cad. Code Crv. Proc. \$ 526(5).

43 Anderson v. Neil Institutes Co., 37 Cal. App. 174, 173 Pac. 779 (1918).

44 The only reported California cases in the entertainment industry which touch on these sections in any manner are Warner Bros. Pictures v. Brodel, 31 Cal.2d 766, 192 P.2d 949 (1948) and De Haviland v. Warner Bros. Pictures Inc., 67 Cal. App.2d 225, 153 P.2d 983 (1944). 